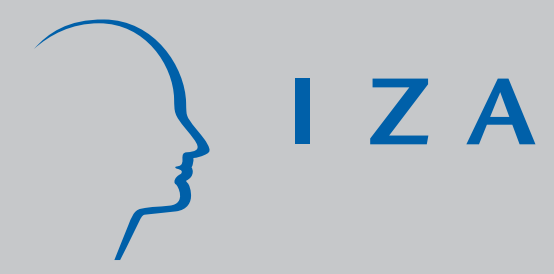

IZADP No. 2228

Immigrant Labour Market Assimilation and Arrival Effects:

Evidence from the UK Labour Force Survey

Ken Clark

J oanne Lindley

July 2006 


\title{
Immigrant Labour Market Assimilation and Arrival Effects: Evidence from the UK Labour Force Survey
}

\author{
Ken Clark \\ University of Manchester \\ and IZA Bonn \\ Joanne Lindley \\ University of Sheffield
}

\section{Discussion Paper No. 2228 \\ July 2006}

IZA
P.O. Box 7240
53072 Bonn
Germany

\author{
Phone: +49-228-3894-0 \\ Fax: +49-228-3894-180 \\ Email: iza@iza.org
}

\begin{abstract}
Any opinions expressed here are those of the author(s) and not those of the institute. Research disseminated by IZA may include views on policy, but the institute itself takes no institutional policy positions.

The Institute for the Study of Labor (IZA) in Bonn is a local and virtual international research center and a place of communication between science, politics and business. IZA is an independent nonprofit company supported by Deutsche Post World Net. The center is associated with the University of Bonn and offers a stimulating research environment through its research networks, research support, and visitors and doctoral programs. IZA engages in (i) original and internationally competitive research in all fields of labor economics, (ii) development of policy concepts, and (iii) dissemination of research results and concepts to the interested public.
\end{abstract}

IZA Discussion Papers often represent preliminary work and are circulated to encourage discussion. Citation of such a paper should account for its provisional character. A revised version may be available directly from the author. 


\begin{abstract}

\section{Immigrant Labour Market Assimilation and Arrival Effects: Evidence from the UK Labour Force Survey*}

We estimate models of earnings and employment outcomes for a sample of white and nonwhite male immigrants drawn from the Labour Force Survey between 1993 and 2002. Immigrants who arrived to enter the labour market are distinguished from those who arrived to complete their education. Diverse patterns of labour market assimilation are found depending on ethnicity and immigrant type. Whites tend to do better than non-whites and labour market entrants do worse than education entrants. There is some evidence of unemployment rates at time of entry to the labour market being associated with permanently lower earnings for non-white immigrants.
\end{abstract}

JEL Classification: J23, J7

Keywords: immigrants, assimilation, earnings, employment

Corresponding author:

Ken Clark

Economics

School of Social Sciences

University of Manchester

Oxford Rd

Manchester M13 9PL

United Kingdom

E-mail: ken.clark@manchester.ac.uk

\footnotetext{
${ }^{*}$ We are grateful to seminar participants at the Universities of Nottingham and Sheffield for useful comments on earlier drafts of this paper. Errors and omissions are the responsibility of the authors. We are grateful to Office for National Statistics and the Economic and Social Data Service for making available the data from the Labour Force Survey.
} 


\section{Introduction}

The labour market performance of immigrants is central to political and public discourse on immigration policy in the UK. In 2001 around 8.3 percent of the UK population were born abroad and the Treasury has estimated that net migration contributes $0.5 \%$ to the economic growth rate. ${ }^{2}$ Recognising the contribution that immigrants make to the economy, the government has endorsed future controlled and selective immigration. Equally, in response to perceived public concerns about the scale of immigration and the motivation of immigrants, it has been emphasised that immigrants should not be dependent on the state. In the Prime Minister's view, “All those who come here to work and study must be able to support themselves"3 How immigrants fare in the labour market is important both for their ability to support themselves and for their contribution to the wider economy, hence in this paper we analyse the earnings and employment outcomes of immigrants observed in the UK labour market over the period 1993-2002.

We focus on two key hypotheses from the literature. The first is that, after arrival in the host country, immigrant labour market outcomes will adjust towards those of nonimmigrant or native workers. This view is often known as the assimilation hypothesis and has received much attention from economists ${ }^{4}$. Assimilation is thought to take place through human capital enhancement: immigrants acquire skills that are specific to the destination country, including knowledge of the labour market and language

\footnotetext{
${ }^{2}$ The population figures were taken from the 2001 Census available from the Office for National Statistics website at http://www.statistics.gov.uk.

${ }^{3}$ Prime Minister's speech to the Confederation of British Industry, April $27^{\text {th }}, 2004$. The full text is available at http://www.pm.gov.uk/output/Page5708.asp.

${ }^{4}$ Chiswick (1978) and Borjas (1985) are classic references for the US while Bell (1997) examines the UK. Antecol et al. (2003) is a recent example which takes a cross-country perspective examining Australia, Canada and the US.
} 
proficiency, allowing them to improve their labour market outcomes relative to natives. The longer the process of assimilation takes, the less successful any cohort of immigrants will be at any given time since arrival.

The second hypothesis we examine is the view that current labour market outcomes for immigrant workers are influenced by labour market conditions when they arrived in the UK. Labour economists often argue that early experiences of unemployment can permanently increase an individual worker's risk of unemployment and reduce their future earnings. This is called the 'scarring hypothesis' (see Arulamapalam et al. (2001) for a recent symposium) and may be relevant for immigrants arriving in a foreign labour market. Scarring can occur for a number of reasons. On the supply side, unemployment spells lead to a loss of firm-specific and general human capital. On the demand side, where information is incomplete, employers may use past unemployment events as a signal of low productivity. This latter mechanism may be particularly important for immigrants if employers are relatively ignorant of the qualifications and skills of workers arriving from overseas. The tendency of immigrants to cluster in particular geographic areas may also lead us to observe effects consistent with scarring if those areas are persistently depressed and the compensating benefits of co-ethnic proximity restrict geographic mobility.

We investigate assimilation and arrival year effects using a sample of native and immigrant workers from the UK's Labour Force Survey (LFS). The labour market outcomes that we focus on are real weekly earnings and employment and we divide our sample of immigrants along two dimensions. First, to account for welldocumented ethnic differences in labour market outcomes, we examine white and 
non-white immigrants separately. There is considerable evidence that non-whites receive differential treatment in the UK labour market (Blackaby et al. (2002) is a recent example) and separating the distinct contributions of immigrant status and ethnicity is important. Second, and more unusually, we compare immigrants who arrive in the UK to enter the labour market, having completed their education at some time in the past, with those who arrive to complete their education in the UK and subsequently enter the labour market. We call this first group "labour market entrants" and the latter group "education entrants". Note that the group of education entrants includes foreign-born children who arrive with their parents as well as adults who arrive to undertake education in the UK.

Kossoudji (1989) also makes the important distinction between labour market assimilation and pre-labour market assimilation. For the education entrants, assimilation consists of labour market assimilation (time spent after leaving full-time education) and pre-labour market assimilation (in the UK education system). Most investigators of the assimilation hypothesis exclude from the estimation sample those who arrive as children or with incomplete education; they therefore focus on labour market assimilation. We explore whether, given their earlier exposure to the language and culture of the UK, such education entrants have outcomes which are closer to their native counterparts than to those immigrants who enter the labour market directly. Education entrants represent around one half of all immigrants in our sample - excluding them risks neglecting a potentially important aspect of the immigrant experience. 
Our work builds on previous UK studies which have used cross-section survey data to paint a picture of immigrant labour market performance. In an early paper Chiswick (1980) used a single cross section of the General Household Survey $(G H S)$ and found that white immigrants earned as much as their native counterparts but that there was, other things equal, a $25 \%$ earnings penalty for non-white immigrants. He found no statistically significant role for years since migration, controlling for other things. Shields and Wheatley Price (1998) also examined earnings and used LFS data from 1992-94. Like Chiswick they found earnings differences between white and nonwhite immigrants. They also emphasised the differential returns to human capital acquired in the home country compared to the host country, with UK human capital generally better rewarded in the UK labour market. Using the same data Wheatley Price (2001) examined the unemployment experience of immigrants and found that more recent immigrants had higher unemployment rates than earlier cohorts.

None of these studies attempts to separate the effects on labour market outcomes of changes in the quality of immigrant cohorts from that of years since migration, however this is a requirement of testing the assimilation hypothesis. In this sense our work is closer to Bell (1997) and Dustmann et al. (2003) each of which used pooled cross section data to create a 'synthetic panel' of immigrant and native workers. Bell (1997), using GHS data from 1973-92, found substantial post-migration earnings growth for non-white immigrants to the UK which he labelled as "strong assimilation". However he also found that white immigrants were predicted to have higher earnings than natives immediately after arrival, an advantage which eroded through time. He labelled this as "dis-assimilation". Dustmann et al. (2003) using LFS data from 1992-2000 distinguished immigrants by ethnicity and by region of 
origin. Wages were broadly predicted to rise with years since migration for non-white immigrants and for whites from the British Commonwealth. Wages fell, however, for white immigrants from Ireland and Europe. Dustmann et al. also examined other labour market outcomes including employment rates where they found that non-white immigrants assimilate towards native levels from an initially inferior position.

Compared to previous work the innovative features of our research are the following. First, we use a larger sample of immigrants and more recent data. Second, and as far as we are aware for the first time using UK data, we investigate the impact of arrival year effects on immigrant earnings and employment. Third, we make the (it turns out) important distinction between those immigrants who arrive with their education complete and those who enter the education system. Finally we employ a semiparametric estimator, which places fewer restrictions on the estimated assimilation profiles than previous work.

Our findings include that:

- there exists considerable diversity in patterns of immigrant assimilation across ethnicity and immigrant type;

- education entrants benefit from exposure to the UK education system

- there are strong ethnic penalties amongst immigrants

- there is some evidence of unemployment rates at time of entry to the labour market being associated with lower earnings for non-white immigrants.

The remainder of the paper proceeds as follows. Section 2 gives an overview of the data while section 3 describes the econometric methods. Section 4 discusses the 
results pertaining to assimilation while section 5 considers arrival year effects. Section 6 concludes.

\section{Data}

The data are drawn from the Labour Force Survey $(L F S)$, conducted by the Office for National Statistics (ONS), and represent pooled annual cross-sections over the period 1993-2002. Since 1992 the Quarterly LFS (QLFS) has a panel design where each sampled address is interviewed for five waves. Interviews take place at three monthly intervals with the fifth interview taking place a year after the first. Each quarter, interviews are achieved at about 59,000 addresses with about 138,000 respondents. The response rate for the first wave of the survey is around 79 percent. Information is collected on earnings, employment and socio-economic characteristics such as age and years of schooling. Between Spring 1992 and Winter 1996, income questions were asked at the respondents final interview. As a consequence, earnings information is available from Spring 1993 (since these joined the survey in Spring 1992). After Spring 1997 income questions were asked at the first and final interview. We use data from the final quarter here. Further details on the sampling methodology and questionnaires are available from the ONS. ${ }^{5}$

Our first labour market outcome of interest is real gross weekly pay in main job and we analyse male, full-time workers aged between 16 and 65 at the time of interview ${ }^{6}$. Our second labour market outcome is whether the survey respondent was employed for pay at the time of the interview. Again we analyse males between 16 and 65 and employment rates are expressed relative to a denominator comprising the employed

\footnotetext{
${ }^{5}$ http://www.ons.gov.uk
} 
and the unemployed; in other words, the self-employed and inactive are excluded from the analysis.

An important component of the analysis is the distinction between those who enter the UK having completed full-time education (labour market entrants) and those who have yet to complete (education entrants). This requires dividing the sample based on information about the year in which individuals left full time education and their year of arrival in the UK. We make the assumption that education is obtained in a continuous block before labour market experience is accrued. This is the standard assumption in the human capital literature. ${ }^{7}$ It is also worth noting that we adopt another standard convention of human capital studies: since we do not observe panel data or work histories, labour market 'experience' is in fact potential experience.

Table 1 provides sample means and standard deviations for some key variables by immigrant and ethnic status (white or non-white). We also further divide our white and non-white samples into labour market entrants and education entrants. The latter of course will have some UK schooling and may have some foreign schooling, but have no foreign labour market experience. Labour market entrants, by contrast, will have no UK schooling but may have foreign schooling and foreign experience ${ }^{8}$. Native born men, white and non-white, are included for comparative purposes.

\footnotetext{
${ }^{6}$ All earnings data were deflated to a common year. We also re-estimated the models using hourly wages and obtained qualitatively similar results.

${ }^{7}$ Of course one could easily imagine an immigrant working either in the origin or destination country for some period before undertaking education in the destination country. Without more detailed panel or life history data it is very difficult to ascertain whether this is the case for any sample member. We can, however, examine the age at which individuals left full time education; if this is implausibly high then the assumption of a single continuous period of education may well be flawed. In the $L F S$ data, the proportion of such workers was relatively small hence we proceed to make the standard assumption.

${ }^{8}$ We focus on years of schooling due to the difficulty in the $L F S$ of comparing qualifications obtained abroad with those obtained in the UK.
} 
Comparing mean earnings, immigrants generally fare better than natives: of the four subcategories of immigrant, only non-white labour market entrants earn less than white natives. White labour market entrants earn more on average than white education entrants, although the reverse is true for non-whites. Amongst natives, labour market entrants and education entrants, non-whites have lower weekly earnings than whites. Comparing employment rates, there is also a substantial ethnic gap. All white workers have roughly the same employment rate, irrespective of their immigrant status, but those for non-whites are lower by up to 15 percentage points. Amongst non-whites, education entrants have higher employment rates than labour market entrants.

For natives, mean potential labour market experience is considerable larger for whites than non-whites (non-whites are younger on average), whilst mean years of schooling are less for whites compared to non-whites. For immigrants, white labour market entrants have less UK labour market experience than their non-white counterparts, although their years of foreign experience and schooling are the same. For education entrants whites have more UK potential experience, more years of UK schooling and less years of foreign schooling compared to non-whites. Not surprisingly, immigrants who arrived with their education complete were older on arrival than those with education incomplete. Although for the latter whites were younger on arrival than non-whites. 


\section{Modelling framework}

Our investigation of immigrant labour market outcomes is based on the following econometric model:

$$
Z_{i}=f\left(Y_{i}\right)+\gamma C_{i}+\delta S_{i}+x_{i} \beta+\varepsilon_{i} \quad i=1, \ldots, n
$$

In equation (1), $Z$ represents a measure of labour market status, $Y$ is years since migration, $C$ is immigrant cohort, $S$ is survey year (year in which the individual was observed), $\boldsymbol{x}$ is a vector of other explanatory variables including human capital and $\varepsilon$ is an error term.

Two measures of labour market status $(Z)$ are used - real weekly earnings in logarithmic form and a discrete dependent variable taking the value 1 if the individual is employed and the value 0 if they are unemployed. We follow the recent literature, particularly Dustmann and Fabbri (2003) and Antecol et al. (2003), in two regards. First, given the difficulty of finding identifying exclusion restrictions, we do not attempt to correct for sample selection bias in either employment or earnings models. Clearly this will affect the interpretation of our results if it is thought that selection bias is a problem. Second, in order to make computation of the semi-parametric estimates more tractable, we use a linear probability model, rather than a probit or logit, to analyse employment status. There turns out to be little difference in the estimated marginal effects of the explanatory variables if a probit model is employed instead.

The years since migration variable $Y$ will capture assimilation effects - how immigrant earnings change with length of residence in the host country. The specification of the function $f(Y)$ is discussed in the next sub-section. $C$ is the immigrant cohort to which 
an individual belongs (thought of here as year of arrival) and captures otherwise unobserved differences in immigrant cohort quality over time. It has been argued that cohort quality changes have been important in explaining immigrant earnings performance in the US and UK. For example, Borjas (1985) suggests that a secular decline in the quality of immigrant cohorts to the US explains the relatively poor performance of some immigrant groups while Bell (1997) using UK data emphasises how the different national origin mix of immigrant waves has affected the overall picture of immigrant earnings. We model $C$ using dummy variables for decade of arrival but, since cohort effects are not central to our work, we do not discuss the results in detail. It turns out that there are no clear, statistically significant, patterns in the cohort dummies in the estimated models.

In order to identify cohort and assimilation effects separately it is necessary to have observations at different points in time. Panel data would be ideal however, like most studies of immigrant earnings, we have to make do with pooled cross section data, sometimes called the 'synthetic panel' approach. The variable $S$ reflects when the individual was observed and captures the effect of secular trends on immigrant outcomes.

The vector $\boldsymbol{x}$ contains other worker characteristics including human capital. We distinguish between human capital (education and potential experience) obtained in the UK and that obtained before arrival in the UK. It also contains marital status, region of residence and, where appropriate, industry of employment. 
For both labour market outcome measures we estimate separate equations for the following four groups: (i) white labour market entrants, (ii) non-white labour market entrants (iii) white education entrants (iv) non-white education entrants. An additional model for white natives is also estimated for comparison purposes. ${ }^{9}$ It is worth noting that most previous studies of immigrant assimilation do not estimate separate regression models for immigrants and natives but rather pool the two groups of workers and allow certain coefficients to vary by immigrant status.

\subsection{Modelling Assimilation}

Not all of the parameters of equation (1) can be estimated since there is perfect multicollinearity: $S \equiv C+Y$. In line with previous studies of immigrant assimilation we adopt the normalisation of fixing the coefficient on $S$ ( $\delta$ - the secular wage growth effect) and estimating the effects of $C$ and $Y$ freely. An estimate of $\delta$ can be obtained from the sample of native workers thus the constraint is equivalent to assuming that the period effect is equal for natives and immigrants.

With respect to the specification of the function $f(Y)$, most studies impose a non-linear functional form - a polynomial - in $Y$ (Bell, 1997; Dustmann et al., 2003; Barth et al., 2004), or divide $Y$ into categories and use dummy variables to represent the categories (Antecol et al., 2003). Since the shape of $f$ is key to the measurement of assimilation we adopt a slightly different approach, which imposes somewhat less structure on the model. Specifically we estimate a semi-parametric version of (1) using a partially linear model (Yatchew, 2003).

\footnotetext{
${ }^{9}$ We compare white and non-white immigrants with white natives throughout. Given the relative sizes of the white and non-white native samples it would make little difference if we used all natives as the comparison group.
} 
Consider rewriting equation (1) as:

$Z_{i}=\boldsymbol{w}_{i} \xi+f\left(Y_{i}\right)+\varepsilon_{i}$

where the vector $\boldsymbol{w}$ includes $C, S$ and $\boldsymbol{x}$ from equation (1). The function $f$ is assumed simply to be some smooth function of years since migration. The data are ordered by $Y$ and quasi-differenced according to the formula: $\left\{\boldsymbol{w}_{i}-\boldsymbol{w}_{i-1}\right\} / \sqrt{ } 2$. Consider the estimated regression on differenced data

$$
\hat{\xi}_{D}=\left(\mathbf{W}_{D}^{\prime} \mathbf{W}_{D}\right)^{-1} \mathbf{W}_{D}^{\prime} \mathbf{Z}_{D}
$$

where $\mathbf{W}_{D}$ is a matrix of quasi-differenced individual observations on the explanatory variables (excluding $Y$ ) and $\mathbf{Z}_{D}$ is the equivalent for the dependent variable. Yatchew (2003) shows that

$$
Z_{i}-\boldsymbol{w}_{i} \hat{\xi}_{D} \approx f\left(Y_{i}\right)+\varepsilon_{i}
$$

and that kernel regression methods applied to the ordered pairs $\left\{Z_{i}-\boldsymbol{w}_{i} \hat{\xi}_{D}, Y_{i}\right\}$ yield a consistent semi-parametric estimator of the function $f$. In the empirical application, the non-parametric estimation was done using a Nadaraya-Watson kernel density estimator. We used a Gaussian kernel and began from a bandwidth chosen according to the formulae in StataCorp. (2001, p. 167). The bandwidth was then adjusted (invariably upwards) to give an appropriate degree of smoothing. The results were 
not particularly sensitive to choice of kernel function and were qualitatively similar to results obtained using other smoothing techniques. ${ }^{10}$

In terms of the amount of structure imposed on the wage and employment profiles, the semi-parametric estimator can be thought of as lying somewhere between a polynomial in $Y$ and modelling each year since migration with a dummy variable.

The former imposes a smooth shape on the function but is restrictive in the sense that it requires symmetry around the function's turning points while the latter imposes no smoothness on the function but may, in a finite sample, be susceptible to sampling error.

\subsection{Modelling Arrival Effects}

To investigate the effect of economic conditions at time of arrival to the UK we replace the cohort dummies in (1) with two variables. The first is the male unemployment rate for the UK in the year of entry to the labour market while the second is the rate of GDP growth. The unemployment rate has been used in a number of studies including Chiswick et al. (1997) and Chiswick and Miller (2002) for the US, and Aslund and Rooth (2003) for Sweden. Conceptually this captures the essence of the scarring hypothesis. We have also included the growth rate to investigate whether more general economic conditions at arrival have any impact on future earnings and employment opportunities (Stewart and Hyclak (1984) do this for the US). The 'macro' variables pertaining to the year in which the immigrant entered the labour market are entered into the regression model: this is year of arrival for labour

\footnotetext{
${ }^{10}$ One further issue with the semi-parametric approach arises from the quasi-discrete nature of the variable $Y$ which is measured as whole years since migration. Since the data are to be sorted by Y, multiple different sort orders are possible. To overcome this problem we took averages over a large
} 
market entrants and year left full-time education for education entrants. Following Chiswick et al. (1997), we also experimented with entering an average unemployment or growth rate based on a 3-year moving average centred on the year of entry to the labour market plus one.

\section{Earnings and Employment Assimilation}

\subsection{Labour Market Entrants}

Figures 1 and 2 report the earnings, employment and assimilation profiles of immigrants who arrived in the UK labour market having completed their education. Figure 1 shows the age-earnings profiles implied by estimation of equation (1) separately on white and non-white labour market entrants, and also on a comparison sample of white natives. The predicted profiles are based on a "typical" worker who enters the labour market aged 16, but who otherwise has the mean characteristics of his respective group. Earnings are then allowed to evolve over the working lifetime in accordance with the estimated semi-parametric function in equation (1).

In the case of earnings (Figure 1(a)), the profiles exhibit earnings growth as time in the UK labour market increases for both white and non-white immigrants. The slopes are broadly similar for the two immigrant groups: from labour market entry to the earnings peak is around $0.44(0.48) \log$ points for whites (non-whites). The big difference between the immigrant groups is in the intercept with whites earning substantially more at all points on the profile. The average difference between white and non-white immigrants is $0.19 \log$ points. This compares to a difference in

number of sorts of the data. Experimentation suggested that estimates converged after 40 replications of the quasi-differenced regression in equation (3) 
average earnings in the raw data between white and non-white natives of $0.10 \mathrm{log}$ points.

While both immigrant groups show evidence of wage growth in the UK labour market, the assimilation hypothesis requires that we compare immigrant earnings to those of natives. The customary approach in the literature is to allow the returns to host country potential experience to vary by immigrant status, a higher return for immigrants being evidence of assimilation. In Figure 1(a) we have plotted the predicted earnings of a comparable native worker to allow a direct comparison of earnings at each point of the working life ${ }^{11}$. It can be seen that on entry to the labour market both white and non-white immigrants earn more than natives however this advantage is soon eroded. Figure 2(a) which plots the difference in log earnings between natives and immigrants shows that native earnings overtake immigrant earnings in around 4 years for non-whites. For whites, immigrant and native earnings are close to the same level from around 15 years after labour market entry. We should note that, particularly for the non-whites, this is the opposite of what the standard view of assimilation proposes. Immigrants are expected to enter the labour market at a lower level of earnings and to overtake their native counterparts.

Figure 1(b) plots predicted employment probabilities for typical workers as described above. Compared to earnings, we observe a quite different picture. Whilst white immigrants exhibit a broadly increasing employment probability over time in the UK labour market, the employment probability of non-whites declines by around 7 percentage points from age 16 to 65 . By the age of 50 , the difference in employment

\footnotetext{
${ }^{11}$ The native comparator has the average characteristics of natives but the same level of schooling (12 years) as assumed in the immigrant profiles.
} 
probabilities between these two immigrant groups is a substantial 20 percentage points. White natives exhibit rapidly increasing employment probabilities over the early years of work, followed by a slight decline after the age of 26. Combining the information for natives and immigrants in Figure 2(b) we see that white immigrants have an initial deterioration in their employment probabilities, due entirely to the strong native employment growth in the early years, followed by a gradual increase over time. Non-white immigrants begin with virtually identical employment probabilities to natives but their relative employment probability declines through time.

\subsection{Education Entrants}

We now turn to examine the labour market assimilation of those immigrants who arrived in the UK to enter the education system, either as adults or as children. Here there is no exact correspondence between years since migration and potential UK experience and this needs to be accounted for when examining assimilation profiles. After estimation of equation (1) separately on the white and non-white education entrants, we consider four individual 'types' similar to those typical individuals used in the preceding sub-section but differentiated by their age at arrival in the UK and their UK educational attainment. Specifically the four types are:

- $\quad$ Type I: arrived aged 5, leaves education aged 16

- $\quad$ Type II: arrived aged 5, leaves education aged 21

- $\quad$ Type III: arrived aged 16, leaves education aged 18

- $\quad$ Type IV: Arrived aged 18, leaves education aged 22. 
Earnings and employment profiles are plotted for these four types in Figure 3. Figure 4 displays the earnings and employment rates relative to white natives with equivalent amounts of (UK) schooling.

Consider panel (a) of Figure 3 which examines earnings for immigrants who entered education on arrival. Age is measured along the horizontal axis and predicted earnings profiles are plotted for each of the four types described above. The first thing to notice about the earnings of education entrants is that compared to labour market entrants the profile is steeper. For white (non-white) education entrants, from entry to peak earnings is around $0.60(0.61) \log$ points while for labour market entrants the figure is $0.44(0.48) \log$ points. Moreover, for both white and non-white immigrants, the benefits of UK education are clear: the individual with 16 years of UK schooling (type II) has the highest earnings at almost every point over the working life compared to the other education entrant types. Indeed, the earnings of non-white immigrants with such a level of UK schooling are very similar to those of comparable whites, in sharp contrast to the earnings of labour market entrants where a substantial ethnic penalty was observed. The predicted earnings of the types with less UK schooling are lower, particularly for the non-white immigrants.

Comparing immigrants and natives with the same level of UK schooling in Figure 4(a) makes it very clear that the returns to non-white immigrants of UK education are extremely important. The types (I and II) with more UK schooling enjoy a premium over natives over a substantial part of their working life. Note also that the individual who arrives in the UK aged 18 and leaves education at age 22 (type IV), while performing well relative to other non white education entrants in Figure 3, actually 
suffers the worst penalty of all, relative to white natives. This is because the native comparator for this type of worker has 18 years of UK schooling which boosts his predicted earnings.

Panel (b) of Figure 3 plots the evolution of employment probabilities for white and non-white immigrants respectively using the four immigrant types outlined above. For both whites and non-whites there is growth in employment probabilities over the first 10 years, and this is particularly strong for non-whites. Differences remain between whites and non-whites, however. After the age of thirty the average white employment rate is $89 \%$ compared to $83 \%$ for non-whites, even for those with the highest level of UK education (type II).

Figure 4(b) completes the picture by displaying the differences between immigrant and native employment rates for the education entrants. For white immigrants there is very little difference between natives and immigrants while for non-whites, an initial employment deficit gradually shrinks through time. The employment deficit reaches zero only for a type I immigrant at the very end of his working life.

\section{Arrival Year Effects}

Tables 2 and 3 report the results of parametric least squares estimates of equation (1) where we replace the cohort dummies with variables reflecting the state of the labour market and wider economy in the immigrant's first year in the British labour market. For immigrants who arrived with their education complete this is their year of arrival to the UK. For immigrants who arrived with their education incomplete this is the year that they left full time education. We estimated six models for each labour 
market outcome. Year of entry unemployment and growth rates were considered singly, then jointly. The same models were then estimated using three-period moving averages (centred on the year after entry) of the aggregate variables.

For both earnings and employment many of the estimated coefficients are insignificantly different from zero. The principal exception is for the earnings of nonwhite labour market entrants where significant negative coefficients on unemployment are found in all four models where unemployment appears. The estimated coefficients range from -0.017 to -0.014 . To give some idea of the economic significance of these results, a coefficient of -0.015 implies that a one percentage point increase in the unemployment rate on entry to the UK labour market is associated with a reduction in earnings of around $1.5 \%$. Over the period during which members of our sample arrived in the UK the male unemployment rate varied between $1 \%$ (1943) and 22\% (1932). Unemployment changes in the initial years of labour market experience could therefore have a quantitatively significant effect on the long-term earnings potential of non-white immigrants.

The only other significant coefficients in Table 2 are negative signs on GDP growth rates for white labour market entrants in two models. These are counter-intuitive: a one percentage point higher growth rate is associated with a reduction in earnings of around $0.9 \%$. UK growth rates over the period were almost always in the interval [$5 \%, 5 \%]$

Turning now to the linear probability models for employment in Table 3 we observe that for non-white labour market entrants, only growth in GDP is statistically 
significant. Non-white labour market entrants who arrived in a period of economic growth enjoy an employment premium. This is not true for their white counterparts, since all the arrival effects are statistically insignificant. For the education entrant immigrants, all the labour market entry variables are statistically insignificant for nonwhites, although whites appear to enjoy an employment premium for high arrival year unemployment rates. Again this is a counter-intuitive result.

In fact these unexpected coefficients are not inconsistent with previous research: the existing literature on arrival year effects and the scarring hypothesis is characterised by somewhat mixed results. Chiswick et al. (1997) find that arrival year unemployment rates exhibit significantly positive coefficients in one specification of an individual employment equation with insignificant coefficients in other specifications. MacDonald and Worswick (1998) find a positive impact of initial unemployment on earnings using Australian data. Stewart and Hyclak (1984) and Chiswick and Miller (2002), both for the US, obtain results more in line with the scarring hypothesis.

\section{Discussion and Conclusions}

In this paper we use Labour Force Survey data to document the impact of arrival year economic conditions and assimilation on the labour market outcomes of immigrants to the UK. The innovative features of our work include the separate analysis of immigrants who arrive in the UK to enter the labour market from those who enter education, the investigation of arrival year economic conditions on labour market outcomes for immigrants and the use of a semi-parametric method to estimate assimilation profiles. Below we summarise and discuss our key results. 
As Figures 2 and 4 attest, there is considerable diversity in patterns of immigrant earnings and employment assimilation. Depending on which of the outcomes, ethnicities or immigrant types is studied, there is evidence of employment rates and weekly earnings rising, falling or staying broadly the same, relative to native workers, as time in the UK labour market increases. The textbook model of assimilation wherein immigrants initially experience a labour market disadvantage which is eroded over time - is not generally supported by these results. Nevertheless there is evidence that, for some groups, labour market outcomes may improve for immigrants faster than for their native counterparts. Beyond the age of 25, white and non-white labour market entrants experience rising relative earnings and the same is true for relative employment rates when we consider white labour market entrants. The declining employment probabilities experienced by non-white labour market entrants stand in marked contrast and may reflect the particular history of non-white immigration to the UK. Many non-white immigrants to the UK were recruited directly to public sector employment in the 1950s and 1960s. We would expect such immigrants to have relatively low unemployment risk on arrival and in the next few years. As time goes by this group would experience shocks and an 'equilibrium' rate of unemployment for those individuals, given their skills and market opportunities, would be established. Such a view would be consistent with the declining relative employment rates we observe.

Our results justify disaggregating the sample of workers born abroad into different immigrant types. The labour market outcomes of education entrants evolve in quite different ways to those of labour market entrants. This is particularly noticeable for 
non-white immigrants where, in earnings terms, the benefits of high levels of UK schooling are clear. Earnings for this group of highly educated workers can match or exceed those of white education entrants, and indeed natives. Investment in UK human capital would seem to offer a relatively high return to this group, and this may be one area of the labour market where ethnic penalties are not the norm. It is also worth noting that our measure of schooling (years in education) is, due to data limitations, somewhat crude and future work could profitably establish what types of educational qualification underlie these high returns for non-white immigrants.

We also investigated whether aggregate economic conditions at the time immigrants enter the labour market can have a permanent impact on their labour market success. There is some evidence that non-white immigrants who arrive in the UK at times of high unemployment and immediately enter the labour market suffer an earnings penalty compared to those who arrive in years of lower unemployment. Arguably, non-white labour market entrants might be expected to be more susceptible to the scarring effect of unemployment than other types of immigrant if employers have less information about their qualifications and backgrounds than they would about white immigrants who originate in countries with education systems and labour markets similar to the UK. For other immigrant groups, and in models where we use the growth rate as the indicator of aggregate economic conditions, the results are either insignificant or, counter-intuitively, suggest that a poorer macroeconomic environment has a permanent, positive impact on immigrant outcomes. There is no consensus in the empirical literature on the size, sign or significance of immigrant arrival effects, however this may be due to data limitations: panel data for the UK have been used to provide convincing evidence of unemployment scarring for native 
workers (Arulampalam, 2001). It is probably asking a lot of our data, using a single aggregate annual unemployment or growth rate as an indicator of individual employment risk, to uncover scarring effects. In other countries, where administrative records allow large samples of immigrants to be analysed, important linkages between aggregate or local labour market conditions and immigrant outcomes have been observed (Aslund and Rooth, 2003; Barth et al., 2004).

Notwithstanding our previous remarks concerning non-white education entrants, on the whole, non-white immigrants perform considerably worse than white immigrants on both indicators of labour market status. Large, persistent ethnic penalties in employment and earnings have been a pervasive feature of the UK labour market since the 1980s. Our results suggest that the ethnic gap is wider for labour market entrants than among the native born population or education entrants. Non-white labour market entrants do experience some earnings growth relative to whites over their working life, however the gap with white immigrants remains. This is likely to reflect their lack of exposure to the UK education system (or similar education systems, as many white labour market entrants will have experienced) and the different occupations and industries in which they work.

From a policy perspective the labour market matters if immigrants are expected by the host country to, in the Prime Minister's words, "support themselves". Evidence of a significant and persistent failure of immigrant labour market outcomes to reach those of natives could be used to bolster estimates of the economic cost of immigration. There is little evidence in our results that, taken as a whole, immigrants in the UK labour market systematically fail to reach high levels of success. Clearly there are 
caveats to this. First, we only observe those immigrants who make it to the labour market and do not observe non-participants or those operating in the shadow economy. Second, patterns of immigration are constantly changing in response to international developments and host country policy changes, hence we should be wary of extrapolating from what previous immigrant cohorts experienced to the performance of future cohorts. Nevertheless, to the extent that the large differences in outcomes that we do observe are related more to white/non-white differences than to immigrant status per se, perhaps that the more important policy question is how best to reduce the detrimental labour market effects of non-white ethnicity. 


\section{Table 1. Sample Means of Key Variables by Immigration and Ethnic Status. QLFS 1993-2002}

\begin{tabular}{|c|c|c|c|c|c|c|c|}
\hline & \multicolumn{2}{|l|}{ Natives } & \multicolumn{2}{|c|}{$\begin{array}{l}\text { Immigrants: Labour } \\
\text { Market Entrants }\end{array}$} & \multicolumn{2}{|c|}{$\begin{array}{l}\text { Immigrants: } \\
\text { Education Entrants }\end{array}$} & \multirow[t]{2}{*}{ Total } \\
\hline & Whites & $\begin{array}{l}\text { Non- } \\
\text { Whites }\end{array}$ & Whites & $\begin{array}{l}\text { Non- } \\
\text { Whites }\end{array}$ & Whites & $\begin{array}{l}\text { Non- } \\
\text { Whites }\end{array}$ & \\
\hline $\begin{array}{l}\text { Mean Gross } \\
\text { Weekly Pay }\end{array}$ & $\begin{array}{l}376.28 \\
(204.18)\end{array}$ & $\begin{array}{l}342.66 \\
(191.55)\end{array}$ & $\begin{array}{l}454.99 \\
(264.13)\end{array}$ & $\begin{array}{l}363.36 \\
(234.78)\end{array}$ & $\begin{array}{l}434.25 \\
(240.52)\end{array}$ & $\begin{array}{l}390.89 \\
(223.19)\end{array}$ & $\begin{array}{l}378.23 \\
(206.971 \\
)\end{array}$ \\
\hline $\begin{array}{l}\text { Employment } \\
\text { Rate }\end{array}$ & $\begin{array}{l}90.43 \\
(0.2898)\end{array}$ & $\begin{array}{l}75.13 \\
(0.4323)\end{array}$ & $\begin{array}{l}89.69 \\
(0.3041)\end{array}$ & $\begin{array}{l}79.39 \\
(0.4045)\end{array}$ & $\begin{array}{l}89.97 \\
(0.3005)\end{array}$ & $\begin{array}{l}81.77 \\
(0.3862)\end{array}$ & $\begin{array}{l}90.14 \\
(0.2981)\end{array}$ \\
\hline Arrival Age & - & - & $\begin{array}{l}26.81 \\
(8.000)\end{array}$ & $\begin{array}{l}26.45 \\
(7.232)\end{array}$ & $\begin{array}{l}6.03 \\
(6.446)\end{array}$ & $\begin{array}{l}11.33 \\
(6.453)\end{array}$ & $\begin{array}{l}17.88 * \\
(11.758)\end{array}$ \\
\hline $\begin{array}{l}\text { UK } \\
\text { Experience }\end{array}$ & $\begin{array}{l}21.51 \\
(12.65)\end{array}$ & $\begin{array}{l}10.07 \\
(8.158)\end{array}$ & $\begin{array}{l}14.03 \\
(13.363)\end{array}$ & $\begin{array}{l}15.99 \\
(11.991)\end{array}$ & $\begin{array}{l}18.39 \\
(11.861)\end{array}$ & $\begin{array}{l}15.85 \\
(9.877)\end{array}$ & $\begin{array}{l}20.97 \\
(12.70)\end{array}$ \\
\hline $\begin{array}{l}\text { Foreign } \\
\text { Experience }\end{array}$ & - & - & $\begin{array}{l}7.87 \\
(7.260)\end{array}$ & $\begin{array}{l}7.43 \\
(6.585)\end{array}$ & - & - & $\begin{array}{l}4.01 * \\
(6.304)\end{array}$ \\
\hline $\begin{array}{l}\text { UK } \\
\text { Schooling }\end{array}$ & $\begin{array}{l}13.02 \\
(2.45)\end{array}$ & $\begin{array}{l}14.29 \\
(2.860)\end{array}$ & - & - & $\begin{array}{l}11.24 \\
(4.890)\end{array}$ & $\begin{array}{l}8.06 \\
(5.315)\end{array}$ & $\begin{array}{l}12.46 \\
(3.572)\end{array}$ \\
\hline $\begin{array}{l}\text { Foreign } \\
\text { Schooling }\end{array}$ & - & - & $\begin{array}{l}14.98 \\
(4.027)\end{array}$ & $\begin{array}{l}14.99 \\
(3.811)\end{array}$ & $\begin{array}{l}3.42 \\
(5.407)\end{array}$ & $\begin{array}{l}7.22 \\
(5.807)\end{array}$ & $\begin{array}{l}10.24 * \\
(7.035)\end{array}$ \\
\hline $\mathrm{N}$ & 204338 & 3382 & 4046 & 4115 & 4356 & 3000 & 223237 \\
\hline $\begin{array}{l}\mathrm{N} \text { for } \\
\text { employed and } \\
\text { positive wage }\end{array}$ & 146719 & 1809 & 2481 & 2185 & 3054 & 1734 & 157982 \\
\hline
\end{tabular}


Table 2. Arrival Year Effects: Earnings

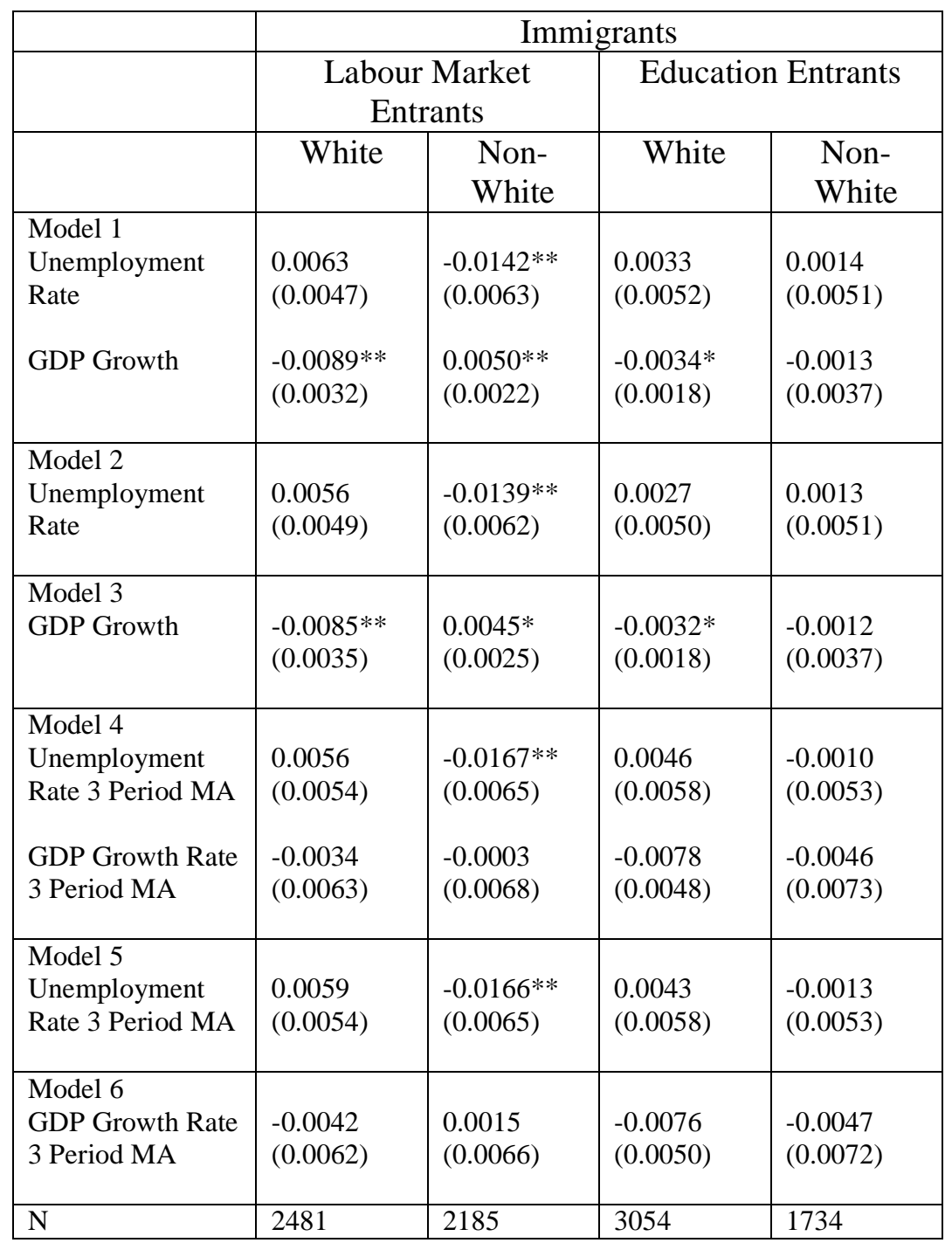

Note:

1. The table contains estimated coefficients and standard errors based on a parametric (quadratic) specification of equation (1) with cohort dummies replaced by the aggregate-level variables.

2. $*$ indicates statistical significance at between 5 and $10 \%$ while $* *$ indicates significance at $5 \%$ or lower. 
Table 3. Arrival Year Effects: Employment

\begin{tabular}{|c|c|c|c|c|}
\hline & \multicolumn{4}{|c|}{ Immigrants } \\
\hline & \multicolumn{2}{|c|}{$\begin{array}{c}\text { Labour Market } \\
\text { Entrants }\end{array}$} & \multicolumn{2}{|c|}{ Education Entrants } \\
\hline & White & $\begin{array}{l}\text { Non- } \\
\text { White }\end{array}$ & White & $\begin{array}{l}\text { Non- } \\
\text { White }\end{array}$ \\
\hline $\begin{array}{l}\text { Model } 1 \\
\text { Unemployment } \\
\text { Rate } \\
\text { GDP Growth }\end{array}$ & $\begin{array}{l}0.0037 \\
(0.0026) \\
-0.0016 \\
(0.0017)\end{array}$ & $\begin{array}{l}-0.0029 \\
(0.0036) \\
0.0063 * * \\
(0.0024)\end{array}$ & $\begin{array}{l}0.0077 * * \\
(0.0030) \\
-0.0012 \\
(0.0018)\end{array}$ & $\begin{array}{l}0.0067 * \\
(0.0037) \\
0.0003 \\
(0.0028)\end{array}$ \\
\hline $\begin{array}{l}\text { Model } 2 \\
\text { Unemployment } \\
\text { Rate }\end{array}$ & $\begin{array}{l}0.0036 \\
(0.0026)\end{array}$ & $\begin{array}{l}-0.0024 \\
(0.0038)\end{array}$ & $\begin{array}{l}0.0076^{* *} \\
(0.0029)\end{array}$ & $\begin{array}{l}0.0068 * \\
(0.0036)\end{array}$ \\
\hline $\begin{array}{l}\text { Model } 3 \\
\text { GDP Growth }\end{array}$ & $\begin{array}{l}-0.0015 \\
(0.0017)\end{array}$ & $\begin{array}{l}0.0062 * * \\
(0.0025)\end{array}$ & $\begin{array}{l}-0.0008 \\
(0.0019)\end{array}$ & $\begin{array}{l}0.0006 \\
(0.0029)\end{array}$ \\
\hline $\begin{array}{l}\text { Model } 4 \\
\text { Unemployment } \\
\text { Rate } 3 \text { Period MA } \\
\text { GDP Growth Rate } \\
3 \text { Period MA }\end{array}$ & $\begin{array}{l}0.0027 \\
(0.0028) \\
-0.0030 \\
(0.0028)\end{array}$ & $\begin{array}{l}-0.0066 \\
(0.0040) \\
0.0056 \\
(0.0038)\end{array}$ & $\begin{array}{l}0.0075 * * \\
(0.0033) \\
-0.0062 \\
(0.0049)\end{array}$ & $\begin{array}{l}0.0068 * \\
(0.0039) \\
-0.0072 \\
(0.0063)\end{array}$ \\
\hline $\begin{array}{l}\text { Model } 5 \\
\text { Unemployment } \\
\text { Rate } 3 \text { Period MA }\end{array}$ & $\begin{array}{l}0.0032 \\
(0.0028)\end{array}$ & $\begin{array}{l}-0.0072 * \\
(0.0042)\end{array}$ & $\begin{array}{l}0.0076 * * \\
(0.0034)\end{array}$ & $\begin{array}{l}0.0069 * \\
(0.0040)\end{array}$ \\
\hline $\begin{array}{l}\text { Model } 6 \\
\text { GDP Growth Rate } \\
3 \text { Period MA }\end{array}$ & $\begin{array}{l}-0.0035 \\
(0.0028)\end{array}$ & $\begin{array}{l}0.0064 \\
(0.0039)\end{array}$ & $\begin{array}{l}-0.0062 \\
(0.0053)\end{array}$ & $\begin{array}{l}-0.0073 \\
(0.0069)\end{array}$ \\
\hline $\mathrm{N}$ & 4046 & 4115 & 4356 & 3000 \\
\hline
\end{tabular}

Note:

1. The table contains estimated coefficients and standard errors based on a parametric (quadratic) specification of equation (1) with cohort dummies replaced by the aggregate-level variables.

2. $*$ indicates statistical significance at between 5 and $10 \%$ while $* *$ indicates significance at $5 \%$ or lower. 
Figure 1.Wage and Employment Profiles: Labour Market Entrants

(a) Earnings

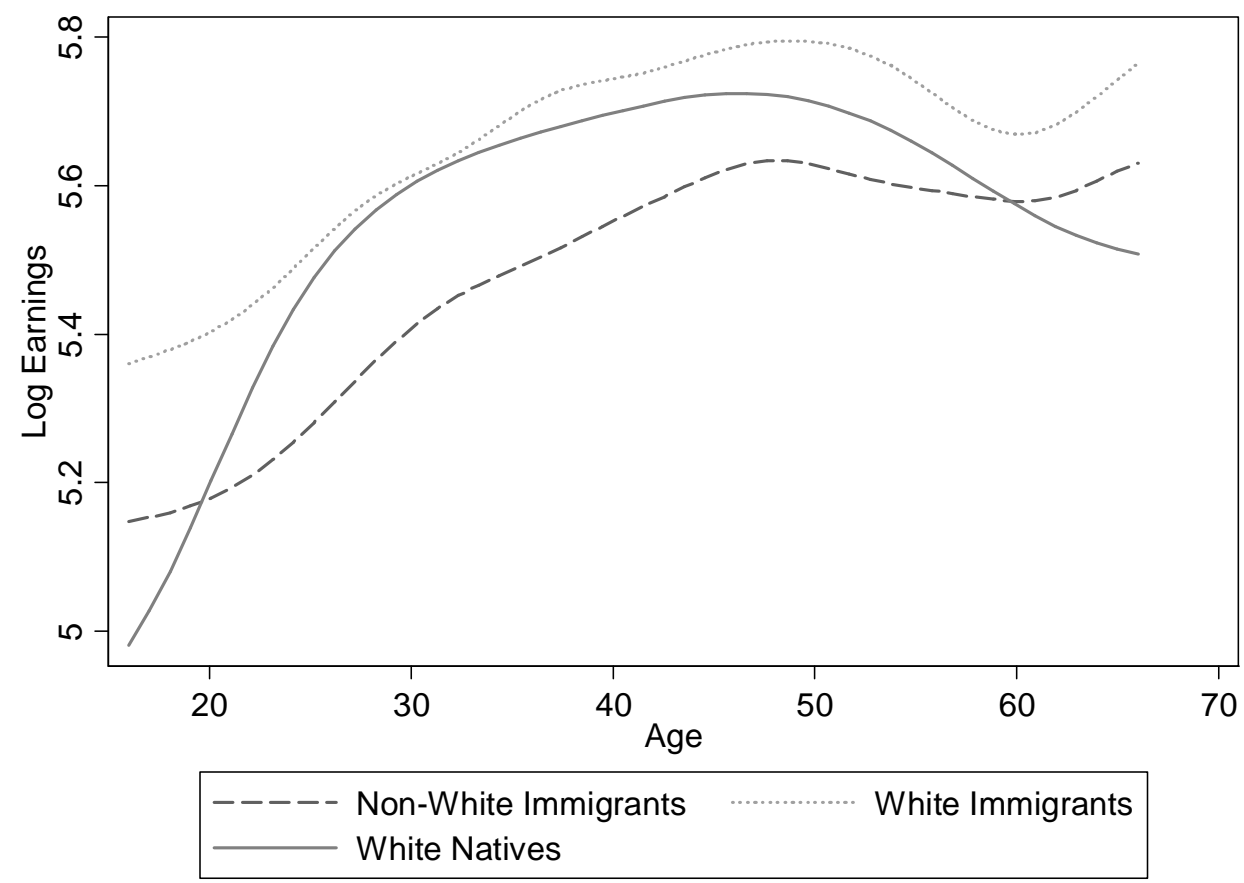

(b) Employment

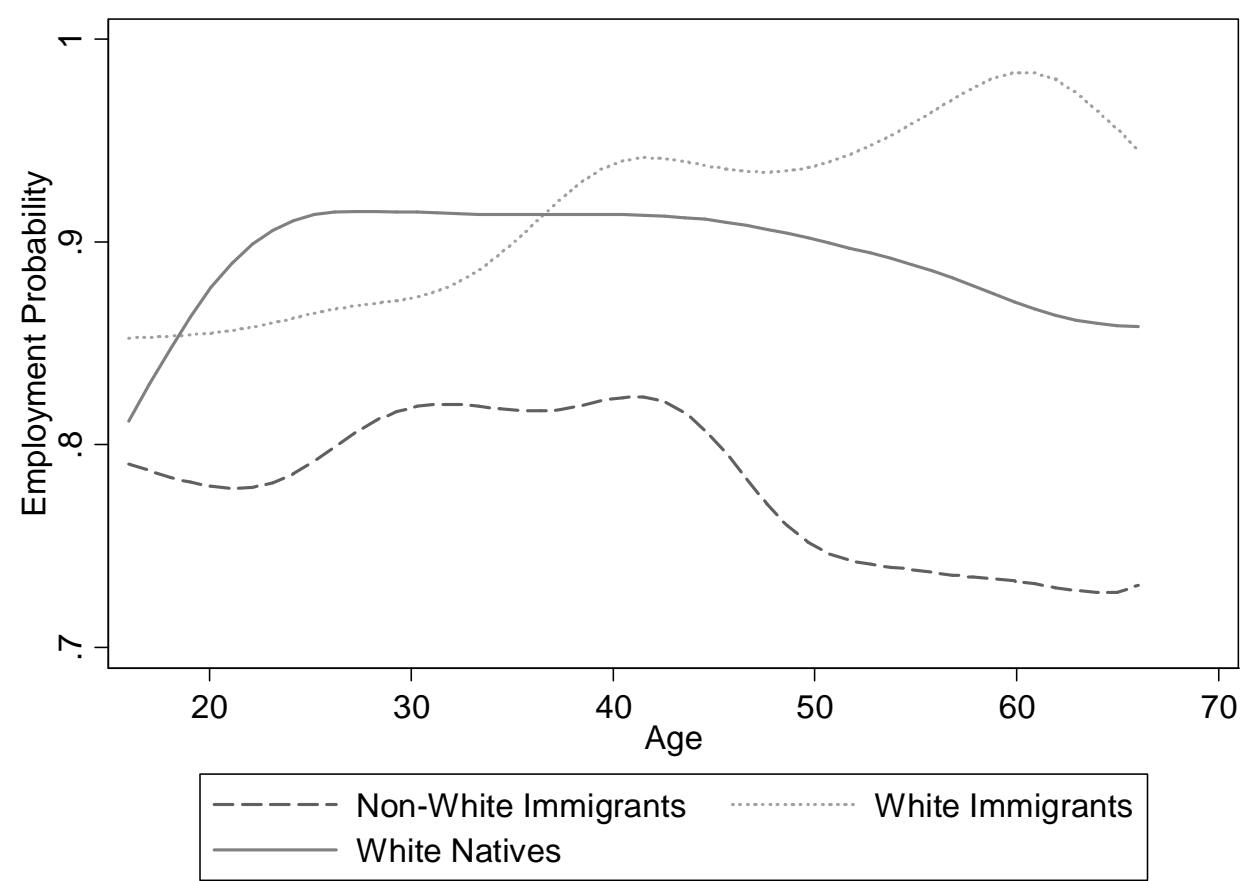


Figure 2. Assimilation: Labour Market Entrants.

Differences between Immigrants and Natives

\section{(a) Earnings}

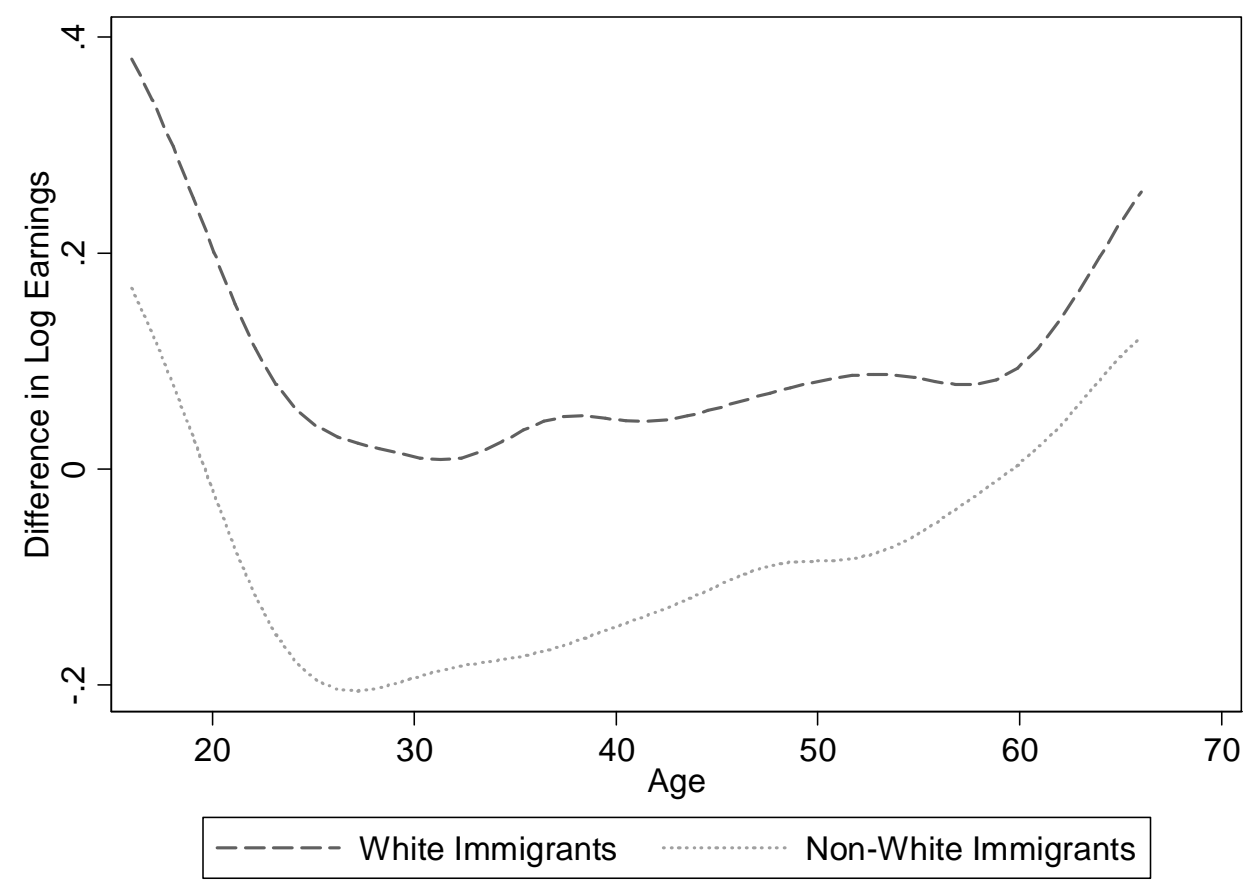

(b) Employment

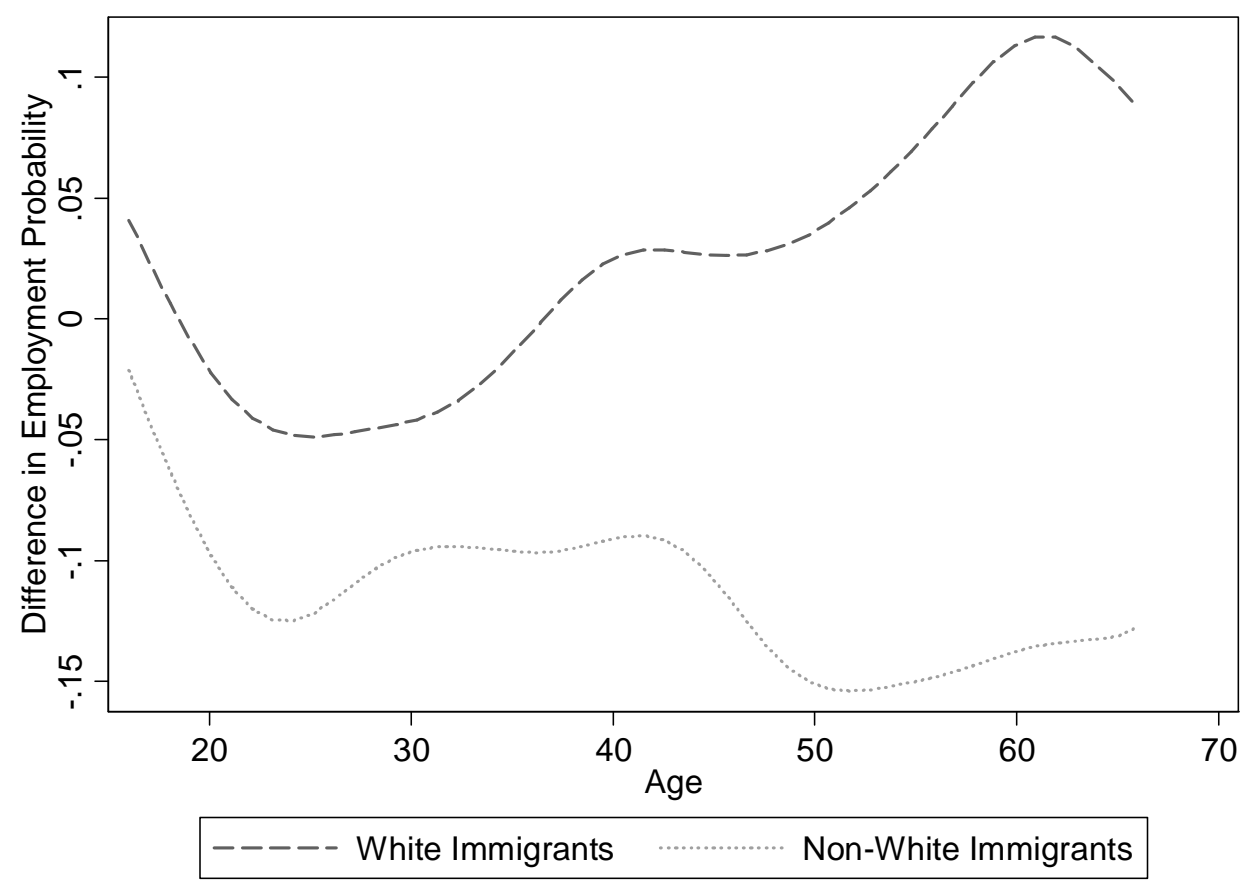




\section{Figure 3.Wage and Employment Profiles: Education Entrants}

\section{(a) Earnings}
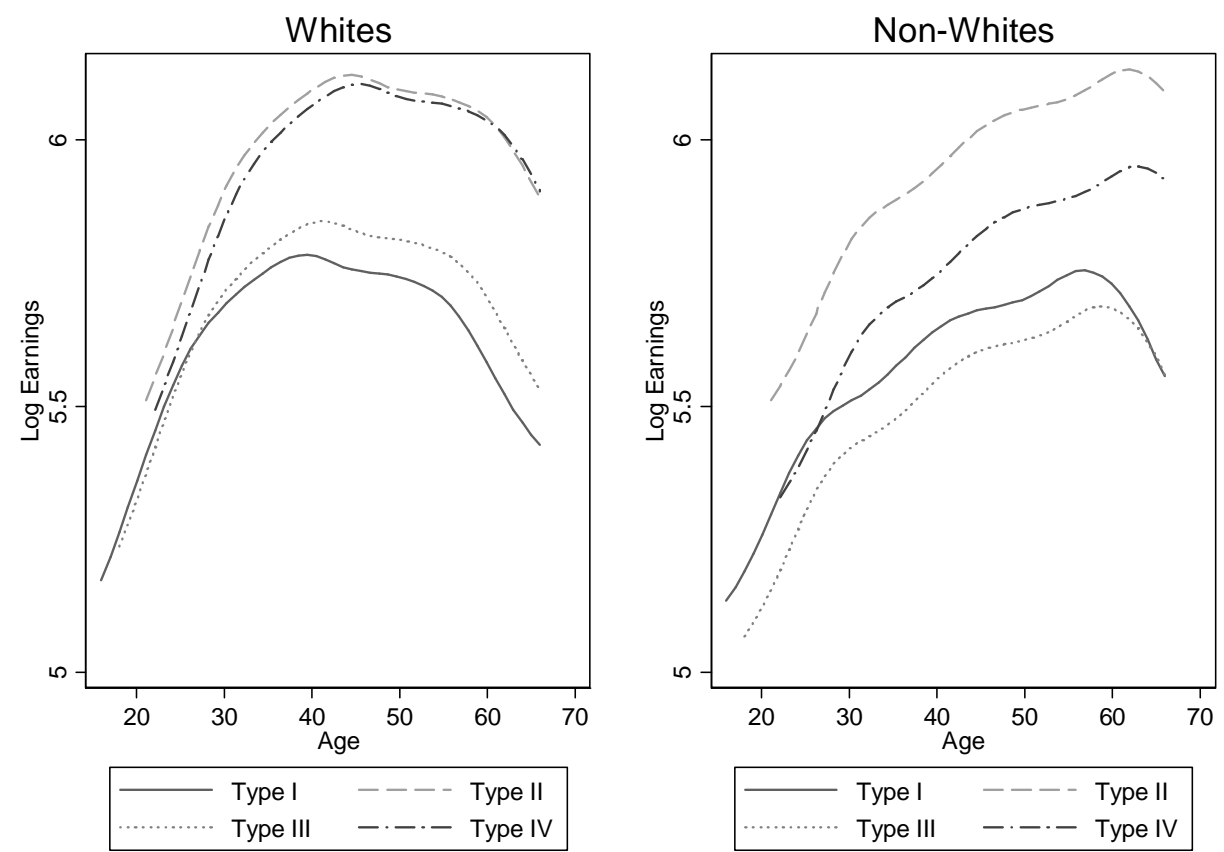

(b) Employment
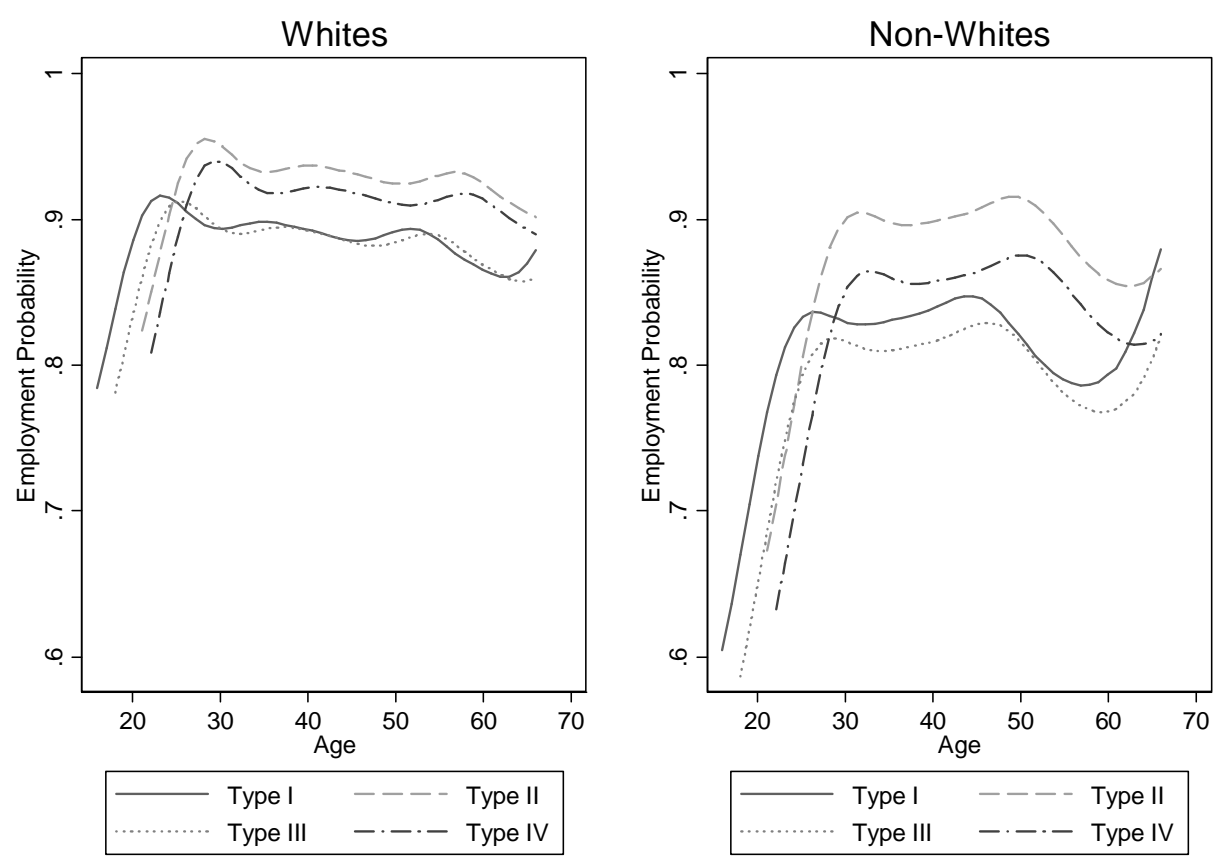
Figure 4. Assimilation: Education Entrants.

Differences between Immigrants and Natives.

\section{(a) Earnings}
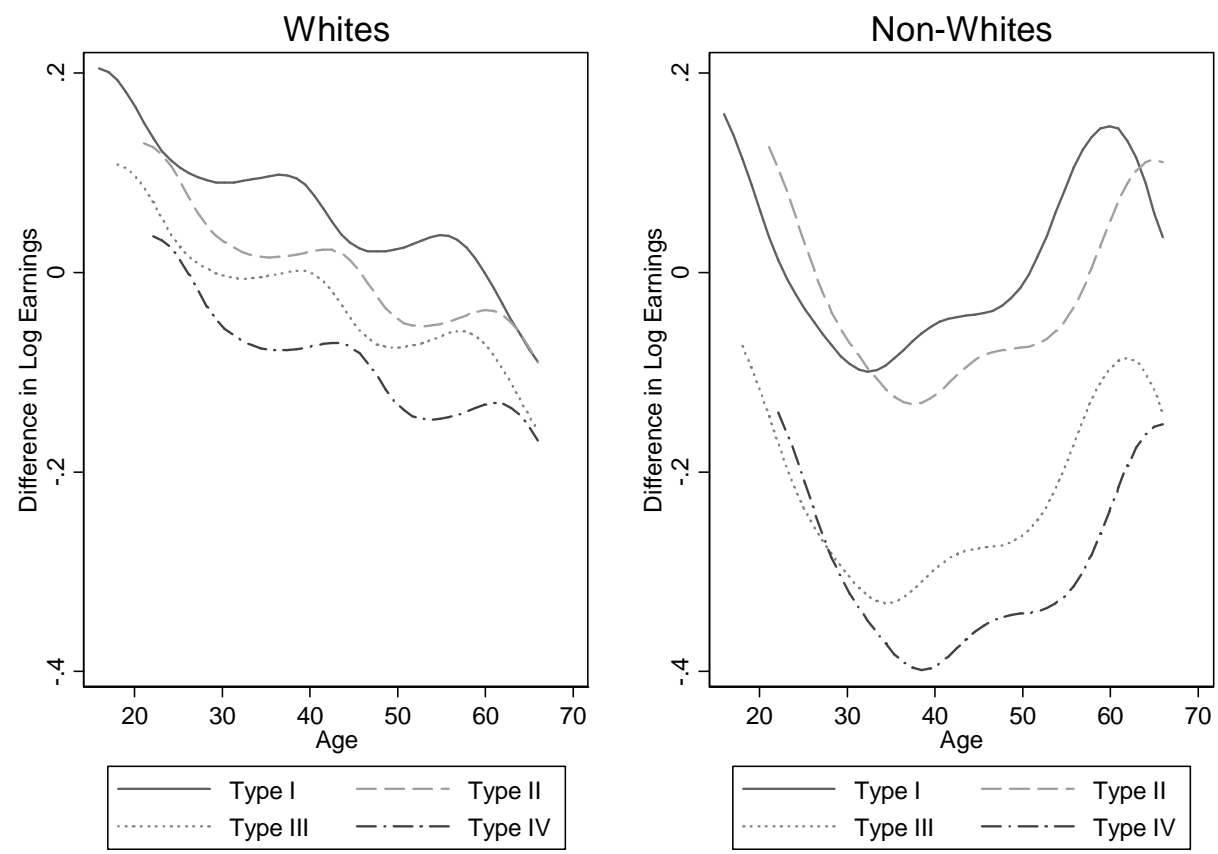

(b) Employment
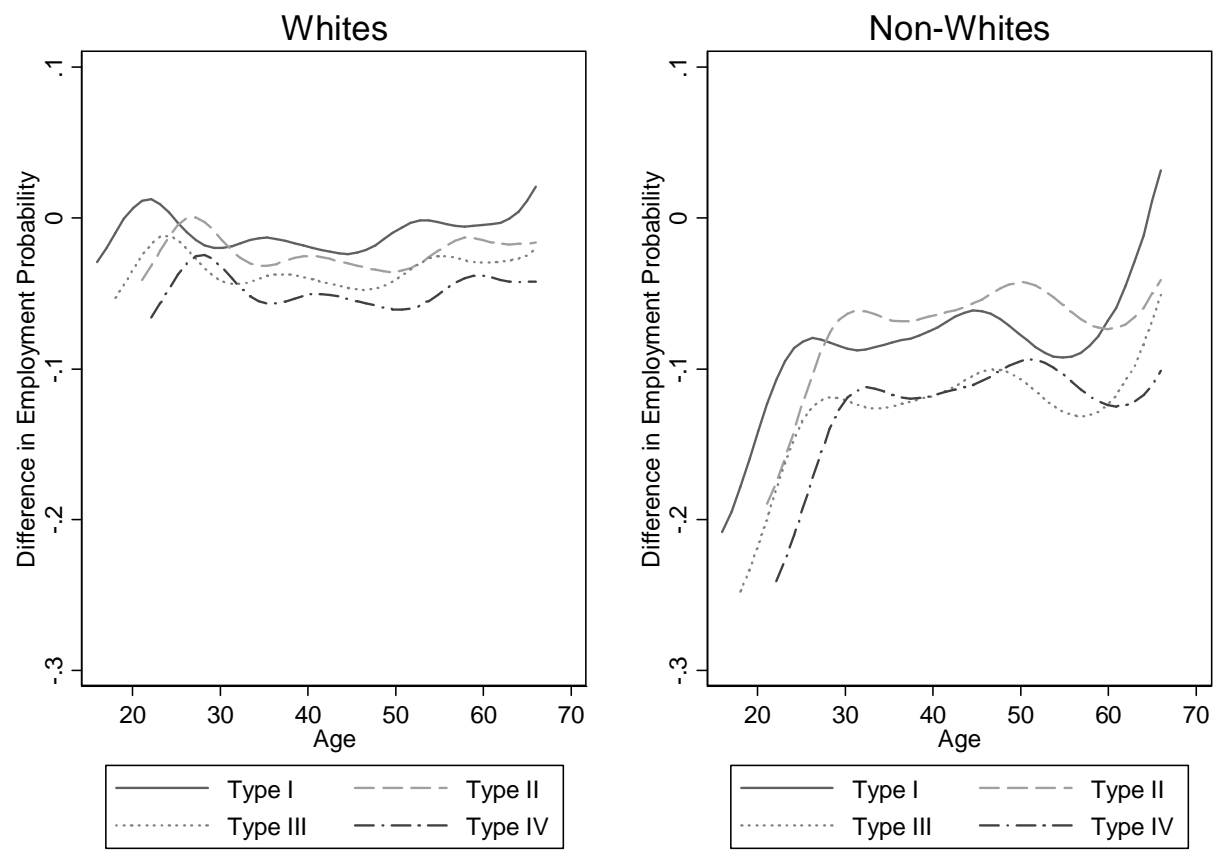


\section{REFERENCES}

Antecol, H., P. Kuhn and S. Trejo (2003), Assimilation via Prices or Quantities? Labor Market Institutions and Immigrant Earnings Growth in Australia, Canada and the United States, IZA Discussion Paper No. 802.

Arulampalam, W. (2001), Is Unemployment Really Scarring? Effects of Unemployment Experiences on Wages, Economic Journal, 111, F585-F606.

Arulampalam, W., P. Gregg and M. Gregory (2001), Introduction: Unemployment Scarring, Economic Journal, 111, F577-F584.

Aslund, O. and D-O. Rooth (2003), Do When and Where Matter? Initial Labour Market Conditions and Immigrant Earnings, paper prepared for EALE Conference, Seville, 2003.

Barth, E, B. Bratsberg and O. Raaum (2004), Identifying Earnings Assimilation of Immigrants under Changing Macroeconomic Conditions, Scandinavian Journal of Economics, 106, 1-22.

Bell, B.D. (1997), The Performance of Immigrants in the United Kingdom: Evidence from the GHS, Economic Journal, 107, 333-345.

Blackaby, D.H., D.G. Leslie, P.D. Murphy and N.C. O’Leary (1998), The Ethnic Wage Gap and Employment Differentials in the 1990s: Evidence for Britain, Economics Letters, 58, 97-103.

Blackaby, D.H., D.G. Leslie, P.D. Murphy and N.C. O'Leary (2002), White/Ethnic Minority Earnings and Employment Differentials in Britain: Evidence from the LFS, Oxford Economic Papers, 54, 270-279.

Borjas, G. (1985), Assimilation, Changes in Cohort Quality, and the Earnings of Immigrants, Journal of Labor Economics, 3, 463-489.

Borjas, G. (1994), The Economics of Immigration, Journal of Economic Literature, $32,1667-1717$.

Chiswick, B. (1978), The Effect of Americanization on the Earnings of Foreign-Born Men, Journal of Political Economy, 86, 897-921.

Chiswick, B. (1980), The Earnings of White and Coloured Male Immigrants in Britain, Economica, 47, 81-87.

Chiswick, B., Y. Cohen and T. Zach (1997), The Labor Market Status of Immigrants: Effects of the Unemployment Rate at Arrival and Duration of Residence, Industrial and Labor Relations Review, 50, 289-303.

Chiswick, B. and P. Miller (2002), Immigrant Earnings: Language Skills, Linguistic Concentrations and the Business Cycle, Journal of Population Economics, 15, 31-57. 
Dustmann, C. and F. Fabbri (2003), Language Proficiency and Labour Market Performance of Immigrants in the UK, Economic Journal, Vol. 113, 695-.717

Dustmann, C., F. Fabbri, I. Preston and J. Wadsworth (2003), Labour Market Performance of Immigrants in the UK Labour Market, Home Office Online Report 05/03, available at http://www.homeoffice.gov.uk.

Kossoudji, S. (1989), The Assimilation of Immigrant Workers: Is it a Labor Market Phenomenon?, Journal of Human Resources, 24, 494-527.

MacDonald, J. and C. Worswick (1998), The Earnings of Immigrant Men in Canada: Job Tenure, Cohort and Macroeconomic Conditions, Industrial and Labor Relations Review, 51, 465-482.

Shields, M. and S. Wheatley Price (1998). The Earnings of Male Immigrants in England: Evidence from the Quarterly LFS, Applied Economics, 30, 1157-1168.

StataCorp (2001), Stata Statistical Software: Release 7.0, Reference Manual H-P, College Station, TX: Stata Corporation.

Stewart, J. and T. Hyclak (1984), An Analysis of Earnings Profiles Among ForeignBorn Men, Review of Economics and Statistics, 66, 292-303.

Wheatley Price, S. (2001), The Unemployment Experience of Male Immigrants in England, Applied Economics, 33, 201-215.

Yatchew, A. (2003), Semiparametric Regression for the Applied Econometrician, Cambridge University Press, Cambridge. 